\title{
ANTARA KUASA KEBOHONGAN DAN KEBEBASAN BEROPINI WARGA: ANALISIS WACANA FOUCAULDIAN PADA HOAKS PANDEMI CORONA DI INDONESIA
}

\author{
Wisnu Martha Adiputra \\ wisnumartha@ugm.ac.id \\ Universitas Gadjah Mada
}

\begin{tabular}{l} 
Article Info \\
\hline Keyword: \\
hoax, discourse analysis, \\
Foucauldian perspective
\end{tabular}

\section{PENDAHULUAN}

Pandemi corona merebak dengan cepat di seluruh dunia. Corona yang pertamakali terdeteksi menginfeksi manusia pada akhir tahun 2019 di Wuhan Tiongkok, dengan cepat menyebar di seluruh dunia. Wabah corona atau covid-19 dengan cepat berkembang menjadi pandemi karena tersebar dengan cepat di seluruh dunia dan perlu upaya optimal secara global untuk mengatasinya. Sudah lebih dari sembilan bulan sejak kasus pertama virus corona pertama kali diidentifikasi di Wuhan, China, pada akhir Desember 2019. Sampai sekarang kasus-kasus baru masih terus dilaporkan di berbagai negara di dunia. Berdasarkan data dari laman Worldometers, pada awal Oktober 2020 jumlah kasus corona yang telah dikonfirmasi di dunia sebanyak 35,38 juta kasus. Sementara, jumlah kasus kematian saat ini (November 2020) telah mencapai lebih dari satu juta kasus dan pasien sembuh sebanyak 26,6 juta orang. Adapun jumlah kasus aktif saat ini tercatat 7,7 juta kasus dengan 7,6 kasus dalam kondisi ringan, dan 66.421 dalam kondisi serius atau kritis. Hingga kini, jumlah kasus terbanyak masih dicatatkan oleh Amerika Serikat (AS) dengan lebih dari 7,6 juta kasus, disusul India, Brazil, Rusia, dan Kolombia. Kondisi pandemi corona masih terus mengalami perubahan dari hari ke hari dan akan semakin tinggi kasus positifnya (Mukaromah, 2020).

Hal lain yang terjadi seiring dengan pandemi corona adalah hoaks yang berkembang di seputarnya, Hoaks tentang pandemi corona sama mematikannya dengan pandemi corona itu sendiri. Hoaks juga mempersulit penanganan pandemi corona karena warga tidak bisa membedakan informasi yang salah dan benar, informasi yang berkualitas dengan yang kurang berkualitas, serta informasi yang benar-benar bermanfaat dan bahkan yang berbahaya. Tidak jarang hoaks tentang corona mengakibatkan korban jiwa kare- 
na sebagaian warga mempercayai informasi mengenai pengobatan yang salah.

Hoaks mengenai corona juga berbahaya karena memberikan informasi yang salah sehingga antisipasi yang dilakukan oleh individu yang mempercayai hoaks juga memberikan efek negatif, bahkan dapat merenggut nyawa (Septiani, 2020). Penyebabnya antara lain karena hoaks membawa pada pengetahuan yang salah dan berefek negatif pada pemikiran dan perasaan sehingga antisipasi yang dilakukan dapat membahayakan jiwa.

Harapan berlebihan atas bebas dari virus corona dan kesembuhan menyebabkan warga tidak lagi mengecek informasi dan kemudian menyebarkan kembali, bahkan menerapkan arahan informasi tersebut yang bersifat fatal. Hoaks mengenai pandemi corona juga berkaitan dengan karakter hoaks jenis lain, misalnya hoaks politik dan bencana, yang juga mengarah pada ekspresi politik negatif dan ujaran kebencian.

Komunikasi politik era digital sekarang ini ternyata memberikan efek negatif, selain efek positif tentunya, di mana warga diberi fasilitas untuk menyampaikan opini dan ekspresinya dengan bebas. Kebebasan beropini warga tersebut ternyata digunakan untuk menyerang pihak lain dengan menyebarkan kebohongan dan kebencian terhadap kelompok lain, sekaligus mengagungkan identitas kelompok sendiri. Negara juga berada dalam dilema ketika mesti menempatkan posisi antara melindungi hak-hak warga tanpa kecuali, termasuk yang berseberangan pendapat dengannya, dengan terus mendorong dan menjaga kebebasan beropini dan berekspresi warga sesuai dengan prinsip demokrasi.

Salah satu upaya tersebut adalah upaya yang dilakukan oleh pemerintah melalui Kementerian Komunikasi dan Informatika Republik Indonesia. Secara rutin pemerintah berusaha menelaah dan mengatasi hoaks melalui laporan hoaks tiap bulan yang dirilis untuk masyarakat luas, yang disebut Laporan Hoaks Bulanan. Upaya mengatasi hoaks tersebut dilakukan bersamaan dengan upaya mengatasi pandemi corona yang sampai pada bulan kesembilan di tahun 2020 ini belum juga menunjukkan tanda-tanda mereda bahkan cenderung terus naik. Upaya antisipasi dan mencegah hoaks tersebut sebenarnya dilakukan oleh banyak pihak di dalam pemerintah, namun pihak yang utama adalah Kominfo.
Upaya mengatasi hoaks pandemi corona oleh pemerintah dapat diamati pula melalui analisis wacana yang hadir di dalam laporan upaya mengatasi hoaks yang ada. Laporan tersebut adalah laporan yang resmi dirilis oleh pemerintah. Wacana tersebut akan dianalisis dalam perspektif Foucauldian, yaitu perangkat analisis dengan menggunakan beberapa pokok pemikiran Michel Foucault, yaitu identitas, kekuasaan, dan pendisiplinan. Informasi hoaks yang merupakan salah satu perwujudan dari wacana adalah elemen penting untuk menunjukkan kepentingan dan kekuasaan yang lebih luas bekerja.

\section{METODE}

Penelitian ini menggunakan metode analisis wacana Foucauldian yaitu perangkat dan prosedur analisis sekumpulan pernyataan dengan menggunakan perangkat pemikiran Michel Foucault, seorang pemikir terkemuka yang mendalami wacana dan memiliki posisi intelektual yang penting dalam menjelaskan wacana. Definisi wacana yang digunakan di dalam riset ini sebagian besar mengikuti yang disampaikan oleh Michel Foucault, yaitu wacana adalah sekumpulan pernyataan. Konsepsi wacana adalah yang pertamakali dikembangkan oleh Foucault walaupun secara spesifik belum melangkah pada rangkaian tahapan untuk menganalisis. Walaupun analisis wacana adalah metode yang pertamakali dikemukakan oleh Foucault, namun arkeologi dan genealogi adalah dua perangkat analisis yang membawa Foucault menjadi pemikir terkemuka (Kendall \& Wickham, 1999).

Wacana secara umum adalah semua bentuk penggunaan bahasa dan bentuk-bentuk tekstual, walau demikian ide esensial dari wacana adalah proses komunikasi dalam berbagai bentuk "teks dan lisan", diadaptasi pada topik, partisipan, dan lokasi sosial yang khusus. Ketiga elemen tersebut dikenal dengan nama "komunitas interpretif". Sementara itu "analisis wacana kritis" berupaya menginvestigasi dominasi dan diekspresikan melalui bentuk-bentuk linguistik yang merupakan kendaraan untuk membawa sentimen dan ideologi yang telah ada sebelumnya (McQuail, 2010: 555). Wacana sendiri adalah praktik dari berbahasa di mana bahasa bukan hanya berfungsi untuk menyampaikan 
realitas dan pengetahuan, tetapi juga menjadi alat untuk berkuasa. Melaui bahasa kekuasaan dipelihara, antara lain sebagai simbol sekaligus cara untuk menuju satu kekuasaan. Bahasa dalam konteks relasi sosial tidak memandang kesamaan antara aturan dengan aturan main penggunaan bahasa tersebut. Menjadi hal yang penting dalam konteks ini adalah tujuan dan makna penggunaan bahasa yang lebih menunjukkan kekuasaan simbolik. Kekuasaan simbolik atas penggunaan bahasa merupakan bentuk kekuasaan untuk mengkonstruksi realitas melalui pemaknaan yang paling dekat dengan kehidupan sosial/kelompok atau seseorang. Perspektif ini lebih menekankan bahwa bahasa tidak hanya sebagai cara komunikasi dalam dunia sosial. Namun lebih dari itu bahasa dapat digunakan untuk mengkonstruksi realitas melalui pemaknaan dunia sosial (Sofyan, 2014: 77).

Pada titik ini hoaks dapat dianggap sebagai pertarungan bahasa, di mana terdapat aturan mengenai perwujudan dan penggunaan bahasa itu sendiri. Demikian juga semua konten di media sosial lokasi hoaks berada, yang memiliki pertarungan dan aturan permainannya sendiri, termasuk bahasa. Melalui hoaks kekuasaan berusaha dijalankan melalui pendisiplinan berdasarkan perspektif Foucauldian. Hal ini dapat diamati antara lain melalui pengemasan pengetahuan dan pemosisian identitas target pengakses potensial dari hoaks.

Penelitian ini berfokus pada konten dan mengelaborasi data kualitatif. Salah satu metode untuk menganalisis konten atau dalam ranah kualitatif disebut sebagai teks, adalah metode analisis wacana. Teknik pengambilan data penelitian ini adalah mendeskripsikan dan mengklasifikasi hoaks di seputar pandemi corona dengan menggunakan laporan hoaks yang dirilis oleh Kementerian Komunikasi dan Informatika Republik Indonesia pada bulan Maret dan Juni 2020.

Dari perspektif yang lain, Norman Fairclough menunjukkan bahwa perspektif sosial dapat dikombinasikan dengan analisis bahasa yang sesungguhnya, antara lain melalui efek-kausal pada teks yang berasal dari kehidupan sosial, perlakuan pada relasi antara teks, peristiwa sosial, dan struktur sosial, dan berimplikasi langsung pada praktik sosial seperti aksi dan interaksi, relasi sosial, orang-orang, dan dunia material (Fairclough, 2003). Perbedaannya dengan perspektif Foucauldian adalah aturan main suatu produk bahasa tersebut muncul adalah elemen yang juga penting selain makna dan relasi antar teks. Hoaks misalnya tidak memiliki aturan main yang rumit misalnya, pada tataran teks yang terbaca, namun cukup rumit bila diamati berdasarkan identitas dan pendisplinan.

Obyek penelitian ini adalah laporan resmi pemerintah yang bernama Laporan Hoaks Bulanan yang disusun oleh Kementerian Informatika dan Komunikasi Republik Indonesia. Laporan yang diteliti adalah laporan bulan Maret dan Juni 2020. Laporan Hoaks Bulanan bulan Maret 2020 dipilih karena Maret adalah bulan pertama masyarakat Indonesia mengetahui dan terimbas oleh dampak pandemi corona. Tanggal 2 Maret 2020 adalah pengumuman resmi pertama bahwa corona telah masuk Indonesia dan telah ada warga yang positif terjangkit virus tersebut. Pengumuman resmi tersebut disampaikan oleh Presiden Joko Widodo. Sementara Laporan Hoaks Bulanan bulan Juni 2020 juga dipilih sebagai obyek penelitian karena Juni adalah bulan di mana mulai terjadi pelonggaran atas aktivitas masyarakat yang sebelumnya sangat dibatasi. Laporan Hoaks Bulanan tersebut dimuat dalam situs resmi Kementerian Informatika dan Komunikasi Republik Indonesia dan juga disebarkan melalui berbagai platform dalam format digital.

Teknik pengumpulan data berikutnya adalah dengan memilah hoaks pada bulan Maret dan Juni 2020. Hoaks yang berkaitan dengan pandemi corona yang dianalisis, sementara yang hoaks yang tidak berkaitan dengan pandemi corona juga dianalisis pada langkah keempat untuk memperkuat keempat tahap lainnya, yaitu untuk mengidentifikasi aturan yang membatasi pernyataan yang muncul. Namun analisis akan tetap memfokuskan perhatian pada hoaks pandemi corona pada kedua bulan tersebut.

Teknik analisis data dilakukan setelah seluruh data yang terdiri dari hoaks pandemi corona yang termuat dalam Laporan Hoaks Bulanan Kominfo didapatkan. Data tersebut akan dianalisis berdasarkan lima tahapan prosedur analisis wacana Foucauldian, yaitu: pertama, mengenali wacana sebagai suatu korpus 
berbagai pernyataan yang memiliki organisasi yang teratur dan sistematik. Hal ini terutama teramati dalam format laporan yang disusun secara kronologis dengan menggunakan pemaparan klasifikasi tertentu. Kedua. mengindentifikasi aturan produksi pernyataan, terutama dalam menentukan tipe hoaks dan penjelasannya. Ketiga, mengindentifikasi aturan yang membatasi yang mungkin dikatakan melalui pernyataan yang disampaikan. Keempat, mengidentifikasi aturan yang menciptakan ruang di mana pernyataan baru dapat dibuat.

Hal ini antara lain teramati melalui kemungkinan relasi dengan hoaks yang tidak terkait dengan pandemi corona. Terakhir, mengidentifikasi aturan yang meyakinkan bahwa praktik (menyampaikan pernyataan) adalah material dan diskursif pada saat yang bersamaan (Kendall \& Wickham, 1999: 42).

\section{TEMUAN DAN DISKUSI}

Kontestasi wacana mengenai hoaks pandemi corona di Indonesia adalah manifestasi hadirnya kuasa melalui wacana dominan dan kuasa-balik melalui wacana alternatif. Di dalam perspektif Foucauldian, wacana adalah sekumpulan pernyataan mengenai suatu isu. Isu dimaknai sebagai perbincangan suatu topik yang berkaitan dengan kehidupan bersama dan mengundang perdebatan. Upaya mengatasi hoaks oleh pemerintah adalah salah satu bagian dari wacana dominan namun dengan karakter yang lebih mendetail dan dengan beberapa pernyataan yang jelas. Di dalam kontestasi berbagai wacana hadir secara bersamaan, baik wacana dominan maupun wacana tanding.

Semua hari pada bulan Maret 2020 terdapat hoaks pandemi corona. Terdapat 234 hoaks mengenai pandemi corona pada bulan ini. Secara umum bulan Maret terdapat lebih banyak hoaks dibandingkan bulanbulan lain, antara lain bila dibandingkan dengan bulan Juni 2020. Sementara itu untuk bulan Juni 2020 hanya terdapat 85 hoaks. Jauh lebih sedikit bila dibandingkan dengan hoaks pada bulan Maret 2020. Kemungkinan hal ini disebabkan oleh masa waktu yang cukup lama setelah pengumuman resmi pertama-kali warga Indonesia terindikasi positif corona. Kemungkinan lain yang dapat dijelaskan dari penyebab jumlah hoaks pandemi corona pada laporan pemerintah berjumlah sedikit ada- lah hadirnya ragam hoaks yang sangat lokal dan tidak terdeteksi oleh laporan yang ruang lingkupnya nasional. Selain itu, kemungkinan lain adalah jalur distribusi hoaks yang berubah melalui media sosial "japri”, jaringan pribadi, yang sangat sulit diamati bila juga tidak muncul dalam jaringan terbuka di media sosial, seperti pada Facebook atau Twitter.

Melalui pemikiran Foucault dapat diamati bahwa kekuasaan bukanlah sesuatu yang melekat dan statis dimiliki oleh salah satu pihak, terutama pihak penguasa. Penguasa memang memiliki otoritas dan perangkat untuk menjalankan kekuasaan namun hal tersebut dinamis. Media sosial menjadikan penggunanya memiliki otoritas dan kecepatan untuk memproduksi dan mendistribusikan pesan secara langsung tanpa melibatkan institusi lain, termasuk negara juga tidak dapat memantau dengan cepat. Inilah yang disebut sebagai kuasa yang berpilin, yang berubah dari institusi kepada warga pengguna biasa. Fenomena kuasa yang terus berpilin ini juga yang semakin menguatkan salah satu karakter kekuasaan dalam perspektif Foucauldian, yaitu kekuasaan itu dinamis dan berada di mana saja, bukan hanya pada pihak-pihak yang secara tradisional memiliki kekuasaan (Bertens, 2014).

Hoaks hadir melalui media sosial dan dipengaruhi oleh konteks sosial, kultural, dan politik di warganet. Dengan demikian, penggunaan media sosial untuk memproduksi dan menyebarkan hoaks tidak sama untuk semua daerah dan juga untuk semua negara. Hoaks tidak akan berarti bila tidak bisa disebarkan dengan cepat dan massif. Penyebar hoaks juga beragam, baik yang disengaja maupun tidak disengaja. Hoaks disebarkan oleh banyak pihak, yaitu: politisi, media lama, media baru, media abal-abal, media sosial, dan individu pengguna media sosial (Ball, 2017). Penyebaran hoaks secara tidak sengaja justru dapat muncul ketika media tidak berhati-hati dalam menjelaskan suatu hoaks. Judul suatu upaya membongkar hoaks menjadi upaya yang keliru ketika malah memicu tersebarnya hoaks tersebut di masyarakat.

Media sosial dalam beragam format adalah sarana utama untuk menyebarkan hoaks. Walau demikian, media sosial selalu berkaitan dengan format konten. Format gambar dan juga video dianggap mem- 
iliki potensi pengaruh yang besar. Tangkapan layar foto atau gambar juga cuplikan video yang seolah-olah merupakan berita dari media arus utama lebih dianggap benar ketika disebarkan melalui media sosial bila dibandingkan konten yang berformat tulisan.

Contoh berita hoaks yang disebarkan melalui media sosial dan mengambil teknik tangkap layar adalah hoaks yang berjudul "Paus Fransiskus Positif Coronavirus" (1 Maret 2020), yang merupakan tangkapan layar berita MCM News. Hoaks lain adalah yang berjudul "Wapres KH.Ma'ruf Amin Mengungkapkan bahwa Susu Kuda Liar dapat Menangkal Virus Corona" (12 Maret 2020) yang disebarkan melalui media sosial dengan tangkapan layar berita di media arus utama.

Tangkapan layar yang disebarkan melalui media sosial rentan diberikan penjelasan apa pun, termasuk hoaks, dan tentu saja tidak menjelaskan konteks dengan detail. Pada hoaks dengan judul "Paus Fransiskus Positif Coronavirus” (1 Maret 2020) banyak pengakses konten tidak bertanya mengenai MCM News, yang ternyata merupakan institusi media yang tidak eksis. Pada hoaks "Wapres KH.Ma'ruf Amin Mengungkapkan bahwa Susu Kuda Liar dapat Menangkal Virus Corona" tidak dikutip seluruhnya dari sumber media bahwa Wakil Presiden berbicara dalam konteks bergurau walau sebenarnya dalam kondisi pandemi corona seperti sekarang ini seorang pejabat publik juga harus lebih berhati-hati dalam menyampaikan pernyataan.

Secara umum Laporan hoaks bulanan Kominfo kurang mendetail dalam memberikan penjelasan mengenai jenis media sosial yang ada, misalnya membedakan media sosial dengan aplikasi percakapan. Dengan demikian pelacakan yang bermakna sulit dilakukan melalui laporan tersebut karena tidak memadai. Laporan tersebut juga tidak secara spesifik menjelaskan format konten awal hoaks sehingga tidak ada pembedaan hoaks berdasarkan tulisan, gambar, ataupun video sehingga upaya mengatasi hoaks pandemi corona tidak bisa spesifik.

Analisis kedua mengenai hoaks pandemi corona memiliki beragam jenis dan aturan produksi. Kuasa yang ditunjukkan oleh wacana dominan hoaks memiliki jenis yang beragam, demikian juga aturan produksinya Sementara itu, melalui wacana tanding dapat diamati bahwa hoaks sulit untuk ditentukan kebenarannya. Dengan demikian, suatu informasi diputuskan merupakan hoaks atau tidak ada pada wewenang pemegang otoritas seperti pemerintah dan polisi. Wacana tanding ini yang banyak dipercaya oleh masyarakat sehingga penentu suatu informasi merupakan hoaks atau tidak harus selalu ditentukan oleh pemerintah, bahkan penegak hukum, sehingga sebagaian masyarakat tidak percaya dengan pihak penentu dari masyarakat sendiri. Hal ini menyulitkan dalam upaya mengatasi hoaks secara umum.

Michel Foucault yang dikenal dengan kritiknya yang sensitif dan komitmen yang tinggi pada ragam gerakan untuk perubahan sosial. Analisisnya pada cara kita mencari kebenaran, makna, pengetahuan, dan alasan di baliknya terbentuk oleh kekuatankekuatan historis (Danaher, et, al., 2000). Prinsip pemikiran Foucault yang utama adalah pengetahuan adalah kuasa, demikian juga kebenaran. Kekuasaan dilihat pada wacana, antara lain pada partisipasi dalam dialog dan sosialisasi dari disiplin dan pertemuan dari beragam entitas (Brown, 2000). Bagi Foucault filsafat adalah cara untuk mempertanyakan kebenaran yang kita terima apa adanya, terutama dari praktik komunikasi institusi yang berkuasa (Gutting (ed), 1994).

Hoaks menjadi sesuatu yang samar dan sulit untuk diatasi karena kondisi masa sekarang ini adalah masa pasca kebenaran di mana fakta bukanlah yang utama dari informasi, melainkan sejauh mana informasi tersebut berpengaruh pada emosi dan bukan pada nalar. Era pasca kebenaran atau post-truth sendiri didefinisikan sebagai relating to or denoting circumstances in which objective facts are less influential in shaping public opinion than appeals to emotion and personal belief (dalam Block, 2019: 2). Hoaks adalah elemen utama dari era post-truth di mana kebohongan dan kebenaran diputarbalikkan. Fakta bukan lagi yang utama tetapi emosi yang menyertainya karena itu istilah post-truth seringkali dipertukarkan dengan post-fact. Hal ini teramati pada hoaks di seputar pandemi corona di mana bukan hanya informasi yang tidak benar yangdisampaikan, melainkan juga emosi pengaksesnya yang juga dipicu dalam konteks negatif maupun positif. 
Hoaks tentu saja tidak menggunakan informasi faktual, namun melalui pemilihan kata tertentu, manipulasi konten yang seringkali sangat tipis dengan kenyataan, dan pemutarbalikkan informasi digunakan untuk menyampaikan setengah kebohongan atau setengah kebenaran (Davis, 2017). Sayangnya, tipe hoaks pada laporan hoaks bulanan oleh Kominfo ini hanya memiliki dua jenis, yaitu hoaks dan disinformasi. Pendefinisian ini tumpang tindih disinformasi sendiri merupakan salah satu jenis dari hoaks. Sebaiknya tipologi yang disusun pemerintah terdiri dari dua tahap, yaitu menentukan hoaks atau bukan dan selanjutnya menjelaskan hoaks tersebut berupa disinformasi, misinformasi, atau malinformasi.

Istilah hoaks sebenarnya sudah lama muncul namun mendapatkan perhatian yang lebih besar di era media sosial belakangan ini, terutama untuk hoaks bidang politik dan kesehatan. Salah satu upaya menjelaskan pengertian hoaks yang mampu menjelaskan dengan baik adalah upaya yang dilakukan oleh UNESCO. Melihat bahwa dampak negatif hoaks sangat besar secara global, organisasi PBB untuk bidang kebudayaan ini merilis banyak pesan yang berupaya menjelaskan dan memberantas hoaks. Salah satu upaya untuk mendefisikan hoaks adalah dengan memilah hoaks dalam tiga jenis, yaitu misinformasi, disinformasi, dan malinformasi.

Misinformasi adalah informasi yang salah yang disebarkan oleh orang-orang yang mempercayainya sebagai hal yang benar. Pengertian salah di sini memiliki dua aspek, yaitu informasi tersebut tidak sesuai kenyataan atau bahkan tidak ada, dan informasi tersebut merupakan gabungan dari beberapa informasi yang tidak saling berhubungan. Sementara, disinformasi adalah informasi salah yang disebarkan oleh orang yang tahu bahwa informasi itu salah. Salah satu contoh disinformasi adalah produksi dan distribusi "berita palsu", yang memiliki potensi besar hadir dalam skala besar, baik secara industri maupun secara politis. Disinformasi adalah kebohongan yang disengaja dan berkenaan dengan orang-orang yang disesatkan secara aktif oleh aktor jahat (Ireton dan Julien Posetti (ed), 2019). Jenis yang ketiga adalah malinformasi, yaitu informasi yang berdasarkan realitas, tetapi digunakan untuk me- rugikan orang, organisasi, ataupun bangsa dan negara lain. Jenis terakhir ini juga sering digunakan untuk memanipulasi informasi privat yang seolah-olah digunakan untuk kepentingan publik.

Praktik jurnalisme yang buruk, gosip, dan desas-desus sangat mungkin merupakan perwujudan paling gamblang dari malinformasi, yang pada awalnya dianggap sebagai fenomena yang biasa namun lambat laun menjadi hoaks yang dipercaya. Walaupun hoaks dapat dibedakan menjadi tiga jenis, konsekuensi ketiganya terhadap sistem informasi dan masyarakat sama negatifnya. Ketiganya juga dapat dikategorikan ke dalam manipulasi informasi yang merupakan ancaman bagi demokrasi di banyak negara apalagi bila secara umum informasi yang beredar kebanyakan berupa hoaks (Vilmer, et.al., 2019). Inilah era yang disebut sebagai era kuasa kebohongan di mana kekuasaan tidak ditopang oleh pencapaian secara faktual melalui informasi yang sahih dan dapat diandalkan, melainkan melalui hoaks dan pendisiplinan identitas untuk beradu dengan identitas yang lain.

Contoh informasi yang menunjukkan bahwa terjadi kebingungan dalam menjelaskan tipe hoaks terdapat pada hoask yang berjudul "Wanita di China Disuntik Mati karena Virus Corona" (2 Maret 2020) yang dikategorikan sebagai disinformasi, dengan hoaks yang berjudul "China Akui Dokter Palestina Penemu Vaksin Corona yang Terbukti Ampuh 100 Persen" (17 Maret 2020) yang didefinisikan sebagai hoaks.

Analisis ketiga adalah upaya yang menunjukkan bahwa terdapat dua hal berkaitan dengan hoaks pandemi corona, yaitu antara yang terkatakan dan yang mungkin disampaikan. Kuasa yang ditunjukkan melalui wacana dominan berupaya memperlihatkan bahwa hoaks pandemi corona pada akhirnya adalah soal politik yang bertujuan menyerang penguasa atau pemerintah. Sementara itu uniknya kuasa-balik yang hadir pada wacana tanding memperlihatkan hal yang serupa dengan wacana dominan namun berposisi sebaliknya, yaitu hoaks pandemi corona digunakan untuk meredam suara kritis kelompok yang menentang penguasa. Wacana tanding terus dipertahankan dan diperkuat dengan penyebaran informasi bahwa orang- 
orang yang mengritik pemerintah saja yang ditangkapi karena menyebarkan hoaks.

Telaah mengenai wacana tanding yang terus dijaga ini berkaitan dengan pemikiran Foucault tentang kuasa, resitensi, dan kuasa-balik, bahkan dapat dilacak mulai dari awal pemikiran Foucault (Gauntlett, 2008). Walau demikian terdapat aspek pemikiran Foucault yang sampai sekarang kurang dipelajari, yaitu mengenai mekanisme-mekanisme kuasa atau strategi kuasa padahal justru tema itulah yang menjadi perhatian Foucault. Aspek ini sangat penting, terutama mengenai mekanisme dan strategi kuasa melalui media sosial yang berbeda dengan media massa dan percakapan di ruang publik seperti yang sejak awal disampaikan oleh Foucault.

Berdasarkan hoaks yang berkaitan dengan pandemi corona pada laporan bulanan, hoaks akan menyasar pada tiga hal terhadap pengakses potensial, yaitu pada pengetahuan (logika), kepanikan (emosi), dan tindakan. Pada pengetahuan misalnya hoaks yang berjudul "Berkumur Air Hangat dengan Garam dan Cuka Bisa Hilangkan Virus Corona (17 Maret 2020)" dan "Covid-19 Bisa Disembuhkan dengan Minyak Kayu Putih" (1 Juni 2020). Pengetahuan sederhana tersebut bagi pengakses potensial hoaks dipercaya kebenarannya karena memberikan semacam harapan agar pandemi corona bisa diatasi.

Sementara itu contoh hoaks yang menyasar emosi dari pengakses potensial adalah hoaks yang berjudul "Di Indonesia Biaya Tes dan Pengobatan Corona Berbayar Karena Tidak Dicover BPJS” (3 Maret 2020), "Jokowi Minta Perbanyak Acara Wisata agar Banyak Rakyat Tewas karena Corona” (24 Maret 2020), dan "WHO Tetapkan Covid-19 sebagai Pandemi Sehari setelah Terima Sumbangan Bill Gates" (19 Juni 2020). Hoaks jenis ini menjadi berpengaruh ketika identitas kelompok sendiri dan kelompok pihak lain semakin ditunjukkan perbedaannya.

Analisis mengenai ruang kuasa baru yang muncul di seputar hoaks pandemi corona adalah langkah keempat analisis wacana Foucauldian yang berupaya mengamati hoaks umum atau hoaks yang tidak bertema pandemi corona. Wacana dominan pada aspek ini adalah hoaks secara umum berada pada karakter yang biasanya muncul, yaitu pada akhirnya hoaks adalah sarana awal untuk menyampaikan ujaran kebencian dan pada akhirnya adalah soal politik identitas.

Misalnya saja pada akhirnya, informasi yang hadir di dalam hoaks umum menyasar pada politik identitas. Kasusnya adalah beredarnya konten yang mengklaim bahwa Indonesia harus menyediakan Rp 30 triliun untuk mengikuti uji klinis vaksin virus corona dari Tiongkok. Kementerian memberikan label disinformasi pada konten ini. Sebab, Tenaga Ahli Utama Kantor Staf Kepresidenan (KSP) Dany Amrul Ichdan mengatakan, pemerintah harus menyiapkan Rp 25 triliun hingga $\mathrm{Rp} 30$ triliun untuk menyediakan vaksin corona. Ini bukan untuk mengikuti uji klinis. Kemudian, kementerian memberikan label disinformasi pada meme yang memuat informasi bahwa angka kematian akibat corona mencapai 1,6 juta orang. Sebab, pada situs Organisasi Kesehatan Dunia (WHO), ada 680.894 korban meninggal dunia akibat corona (Annur, 2020). Sasaran hoaks pandemi corona sebenarnya mirip dengan hoaks kontestasi politik dan bencana yang telah marak sebelumnya masa pandemi.

Untuk memahami pengertian media sosial pada era komunikasi digital diperlukan pemahaman apa yang dimaksud dengan arti sosial tersebut, yang dapat bermakna sekadar merangkaikan banyak individu atau berkaitan pula dengan dampaknya. Namun sebenarnya melalui ragam teori sosial yang digunakan untuk memahami media sosial adalah konsep sosialitas di dalam masyarakat, termasuk fakta sosial, relasi sosial, tindakan sosial, pekerja kooperatif, dan komunitas (Fuchs, 2014: 48). Media sosial memiliki lapisan pengetahuan untuk dimengerti dan bukan sekadar perangkat yang digunakan oleh warga untuk mendapatkan dan menyebarkan informasi.

Menurut Ketua Masyarakat Anti-Fitnah Indonesia (Mafindo), Septiaji Eko Nugroho, menyampaikan bahwa berbagai narasi yang terkait pencegahan dan pengobatan ini sepertinya banyak muncul di tengah masyarakat Indonesia yang memang cenderung mudah percaya dengan narasi-narasi yang berbasis testimony based (dalam Halim, 2020). Pernyataan tersebut sekaligus menyebutkan kelemahan sebagian warga 
Indonesia, yaitu cenderung mudah percaya pada informasi dan kemudian dengan mudah pula menyebarkannya.

Sementara itu, dari sisi penindakan hukum, pada bulan April 2020 saja sudah terdapat tujuh puluh tujuh orang menjadi tersangka karena menyebarkan hoaks mengenai pandemi corona. Menkominfo Jhonny G. Plate menyampaikan pemerintah telah menindak tegas sekitar tujuh puluh tujuh orang yang menyebar berita hoaks selama pandemi corona di Indonesia. Sekitar dua belas orang sudah ditahan akibat menyebar hoaks pandemi corona (Taher, 2020).

Ruang-ruang pada hoaks umum seringkali tidak terduga, misalnya saja ditunjukkan oleh dua hoaks sebagai berikut ini: "Himbauan Jokowi "Jangan Keluar Rumah Kalau Bosan Nonton Drakor Saja" (18 Maret 2020) dan "Jokowi Tewas Gantung Diri "Dasar Presiden PKI"” (8 Juni 2020). Ruang budaya populer, yaitu drama Korea dapat tiba-tiba menjadi pijakan untuk hoaks yang sebenarnya menyasar target yang lebih jauh dibandingkan hanya sekadar informasi yang dipelintir, namun "mendisiplinkan" identitas melalui pernyataan-pernyataan yang disampaikan tentang kelompok sendiri dan kelompok lain.

Analisis kelima adalah upaya menunjukkan bahwa hoaks pandemi corona menghubungkan aspek material dan diskursif sekaligus. Efek yang paling berat dari hoaks pandemi corona adalah munculnya covidiot, istilah yang cenderung kasar untuk menyebut seseorang yang mengabaikan nasihat dan peringatan kesehatan publik dan keamanan berkaitan dengan corona. Covidiot juga secara umum menganggap semua informasi yang berkaitan dengan corona adalah hoaks, antara lain tidak menggunakan masker atau mengatakan bahwa corona hanyalah seperti sakit flu biasa. Mereka juga akan mengatakan bahwa tindakan mereka adalah termasuk hak konstitusional dengan tidak mematuhi protokol kesehatan, termasuk semua panduan yang diberikan oleh pemerintah untuk mengatasi pandemi (Miller, 2020).

Analisis Foucault pada kekuasaan secara umum termanifestasi pada masyarakat, sekolah, rumah sakit, pabrik, keluarga, dan beragam bentuk kumpulan individu yang terinstitusionalisasi. Kekuasaan bisa tid- ak terlihat dengan jelas dan keras namun secara inheren memasuki beragam obyeknya (Rabinow (ed), 1984). Kekuasaan juga dapat mewujud pada sesuatu yang nyaman dan tidak mengekang seperti dalam seksualitas (Foucault, 2000). Informasi di dalam hoaks pandemi corona pada dasarnya menunjukkan kekuasaan secara samar dapat muncul dan berpengaruh pada pengakses potensialnya.

Sumber informasi adanya hoaks disampaikan oleh media arus utama, beragam gerakan cek fakta, dan gerakan masyarakat sipil yang mengambil beragam topik, termasuk yang tidak berhubungan secara langsung dengan hoaks, misalnya kedaulatan informasi dan perlindungan informasi personal. Sebaiknya pemerintah menyediakan saluran untuk pendidikan literasi digital dan pihak-pihak lain yang berupaya mengatasi hoaks. Hoaks sebenarnya marak tidak hanya di Indonesia, namun juga merupakan permasalahan global yang hadir di banyak negara, termasuk di negara yang dikategorikan sebagai negara maju. Hoaks menjadi urusan global karena teknologi informasi dan komunikasi bergerak melintasi batas negara (Haciyakupoglu, 2018) dan politik identitas sedang menguat. Dengan demikian, upaya mengatasi hoaks di seputar pandemi corona sesungguhnya merupakan bagian dari upaya negara untuk memenuhi hak-hak warga atas informasi yang berkualitas.

\section{KESIMPULAN}

Berdasarkan data dan analisisnya yang telah dipaparkan, penelitian ini memiliki kesimpulan sebagai berikut: pertama, melalui analisis wacana Foucauldian didapatkan bahwa hoaks pandemi corona adalah pernyataan yang teratur dan sistematis. Salah satu pernyataan pada wacana yang dibawa oleh pemerintah antara lain adalah hoaks disebarkan melalui media sosial yang merupakan perangkat yang dimiliki oleh warga sekarang ini.

Kedua, berdasarkan ragam aturan produksi dan jenis hoaks dapat disimpulkan bahwa pemerintah menyadari hoaks memiliki tipologi. Sayangnya, pernyataan ini tidak memiliki efek diskursif karena tipologi yang tidak jelas antara hoaks dan disinformasi. Dari 
banyak sumber atau referensi utama didapatkan bahwa disinformasi sendiri adalah bagian dari hoaks bersama dua jenis yang lain, yaitu misinformasi dan malinformasi.

Kesimpulan ketiga menunjukkan bahwa hoaks $\underline{\text { seputar pandemi corona memberikan ruang di antara }}$ yang terkatakan dan mungkin disampaikan. Secara eksplisit berdasarkan analisis hoaks pada bulan Maret dan Juni 2020 didapatkan sasaran obyek yang beragam. Obyek tersebut berakaitan dengan penguatan identitas $\underline{\text { sendiri atau serangan terhadap identitas yang lain. }}$

Keempat, kesimpulan terkait ruang kuasa baru seputar hoaks pandemi corona berkaitan dengan berbagai hoaks lainnya di luar hoaks pandemi corona. Pernyataan yang menjadi bagian dari wacana pemerintah adalah hoaks adalah awal dari ujaran kebencian dan menjadi sarana bagi penguatan politik identitas yang negatif. Hoaks-hoaks lain di luar pandemi corona tetap mengindikasi penguatan identitas kelompok sendiri dan menyerang kelompok lain yang memiliki identitas yang berbeda.

Kesimpulan terakhir atau kelima menunjukkan bahwa aspek material dan diskursif dari hoaks pandemi corona seringkali berhubungan. Melalui analisis hoaks pada laporan hoaks bulanan didapatkan bahwa sumber hoaks sebenarnya bisa dilacak. Hoaks berasal dari saluran-saluran komunikasi yang sebenarnya spesifik dan berasal dari dalam maupun luar negeri. Pernyataan yang muncul dari aspek ini adalah sumber dan efek hoaks dapat dilacak dan diprediksi.

Aspek material dari sumber hoaks beserta antisipasinya hadir dalam laporan hoaks bulanan oleh pemerintah. Efek diskursif dari hoaks juga terprediksi dalam analisis wacana yang dilakukan. Dengan demikian, upaya antisipasi dan mencegah hoaks oleh pemerintah, bahkan juga oleh negara, sebenarnya bisa mengutamakan antisipasi, pengawasan, dan pemulihan atau rekonsialisasi. Upaya yang merupakan penindakan sebaiknya berada dalam koridor sosiokultural dan tidak mengutamakan penindakan hukum.

\section{DAFTAR PUSTAKA}

\section{Buku dan Artikel Jurnal}

Ball, James (2017). Post-Truth: How Bullshit Conquered the World. London: Biteback.

Bertens, K. (2014). Sejarah Filsafat Kontemporer: Prancis. Jakarta: Gramedia Pustaka Utama.

Block, David (2019). Post-Truth and Political Discourse. Cham: Palgrave Macmillan.

Brown, Alison Leigh (2000). On Foucault: A Critical Introduction. Belmont: Wadsworth.

Danaher, Geoff, Tony Schirato \& Jen Webb (2000). Understanding Foucault. London: Sage.

Davis, Evan (2017). Why We Have Reached Peak Bullshit and What We Can Do about It. London: Little Brown.

Fairclough, Norman (2003). Analysing Discourse: Textual Analysis for Social Research. London: Routledge.

Foucault, Michel (2000). Seks dan Kekuasaan: Sejarah Seksualitas. Jakarta: Gramedia Pustaka Utama.

Fuchs, Christian (2014). Social Media: A Critical Introduction. London: Sage.

Gauntlett, David (2008). Media, Gender and Identity: An Intoduction. Second Edition. London: Routledge.

Gutting, Gary (ed) (1994). The Cambridge Companion to Foucault. Cambridge: Cambridge University Press.

Haciyakupoglu, Gulizar, Jennifer Yang Hui, V. S. Suguna, Dymples Leong, Muhammad Faizal Bin Abdul Rahman (2018). Countering Fake News: A Survey of Recent Global Initiatives. Singapore: RsiS Nanyang Technological University.

Ireton, Cherilyn dan Julien Posetti (ed) (2019). Jurnalisme, "Berita Palsu” dan Disinformasi: Buku Pegangan untuk Pendidikan dan Pelatihan Jurnalisme. Paris: UNESCO. 
Kendall, Gavin \& Gary Wickham (1999). Using Foucault's Methods. London: Sage.

McQuail, Denis (2010). Mass Communication Theory. Sixth Edition. London: Sage.

Rabinow, Paul (ed) (1984). The Foucault Reader. London: Penguin Books.

Sofyan, Nur (2014). Bahasa sebagai Simbolisasi Mempertahankan Kekuasaan. JURNAL INTERAKSI, Vol III No.1, Januari 2014 : 75-84

Vilmer, Jean-Baptiste Jeangène, Alexandre Escorcia, Marine Guillaume, Janaina Herrera (2018). Information Manipulation: A Challenge for Our Democracies. Paris: Policy Planning Staff (CAPS, Ministry for Europe and Foreign Affairs) and the Institute for Strategic Rechearch (IRSEM, Ministry for the Armed Forces).

\section{Laporan dan Dokumen Negara}

Direktorat Pengendalian Aplikasi Telematika (2020). Laporan Isu Hoaks Maret 2020. Direktorat Jenderal Aplikasi Telematika, Kementerian Komunikasi dan Informatika Republik Indonesia.

Direktorat Pengendalian Aplikasi Telematika (2020). Laporan Isu Hoaks Juni 2020. Direktorat Jenderal Aplikasi Telematika, Kementerian Komunikasi dan Informatika Republik Indonesia.

\section{Media Online}

Annur, Cindy Mutia (2020, Agustus 5). Ada 1.016 Hoaks Corona, Salah Satunya Pandemi Untungkan Menteri Nadiem. Katadata.co.id. Diakses dari https://katadata.co.id/ desysetyowati/digital/5f2a6b08ab749/ada1016-hoaks-corona-salah-satunya-pandemiuntungkan-menteri-nadiem, pada tanggal 15 September 2020, pukul 13.25 WIB.

Halim, Devina (2020, September 5). 6 Bulan Pandemi Covid-19: Hoaks dan Teori Konspirasi yang Memperparah Penanganan.... Kompas.com. Diakses dari https://nasional.kompas.com/ $\mathrm{read} / 2020 / 09 / 05 / 09090921 / 6$-bulan-pandemi- covid-19-hoaks-dan-teori-konspirasi-yangmemperparah?page=all, pada tanggal 15 September 2020, pukul 12.45 WIB.

Miller, Korin (2020, Juli 15). What Does 'Covidiot' Mean, and Who Qualifies as One? Health.com. Diakses dari https:// www.health.com/condition/infectiousdiseases/coronavirus/what-does-covidiotmean, pada tanggal 5 Oktober 2020, pukul 12.56 WIB.

Mukaromah, Vina Fadhrotul (2020, Oktober 5). Update Covid-19 Dunia 5 Oktober: 35,38 Juta Orang Terinfeksi Virus Corona. Kompas.com. Diakses dari https://www.kompas.com/tren/ $\mathrm{read} / 2020 / 10 / 05 / 073710265 /$ update-covid-19dunia-5-oktober-3538-juta-orang-terinfeksivirus-corona?page $=$ all, pada tanggal 5 Oktober 2020, pukul 14.47 WIB.

Septiani, Ayunda (2020, Agustus 12). Percaya Hoax Disebut Lebih 'Mematikan' dibanding Corona, Termasuk di Indonesia. Detik.com. Diakses dari https://health.detik.com/beritadetikhealth/d-5129588/percaya-hoax-disebutlebih-mematikan-dibanding-corona-termasukdi-indonesia, pada tanggal 7 September 2020, pukul 19.10 WIB. 